\title{
Ink in Herculaneum: A Survey of Recent Perspectives
}

\author{
Vincenzo Damiani
}

\begin{abstract}
This paper provides a brief survey of the latest research concerning the types and chemical characteristics of the ink used in the Graeco-Latin papyri from Herculaneum. According to the communis opinio, the Herculaneum inks are no exception to the widespread use of carbon black ink in antiquity. This position has been recently revised on the basis of studies that use X-Ray Phase Contrast Tomography (ХРCT) to show a significant presence of lead in the ink of some fragments. This important discovery allows for the possibility of using lead as a contrast agent in order to distinguish the writing from the support in still rolled volumina through exposure to synchrotron light.
\end{abstract}

\section{Keywords}

Herculaneum papyri - X-Ray Phase Contrast Tomography (ХРСТ) - carbon black ink - lead

\section{Ink in Greek and Latin Papyri}

According to ancient testimonies, the ink used in Greek papyri was produced from soot (carbon black/charcoal that functioned as pigment) resulting from the combustion of materials such as resin, oil or wood, mixed with a carbohydrate binder, usually gum arabic from acacia trees (at a ratio of 1 uncia of gum to 3 unciae of carbon $)^{1}$ in order to obtain blocks that form a suspension when mixed with water: ${ }^{2}$

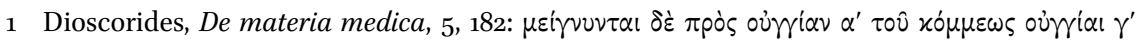
$\lambda$ rrvúos ("Three unciae of soot are mixed with one uncia of gum"). All the translations are mine, if not indicated otherwise.

2 Cf. the contribution by Ira Rabin in this volume, in the section Carbon inks. The ink was then sold by weight: see Gertrud Herzog Hauser, "Tinte," in Realencyclopädie der Classischen 
inde collecta (scil. fuligo) partim componitur ex gummi subacta ad usum atramenti librarii, reliquum tectores glutinum admiscentes in parietibus utuntur.

VITRUVIUS, De architectura, 7, 10

Then, once the soot has been collected, a part of it is mixed and kneaded with gum to make writing ink; the painters mix the rest with glue to use it on walls.

omne autem atramentum sole perficitur, librarium cumme, tectorium glutine admixto.

PLINIUS, Naturalis historia, 35, 25, 43

All black pigments require exposure to the sun; ink for writing is obtained by mixing with gum, ink for painting by mixing with glue.

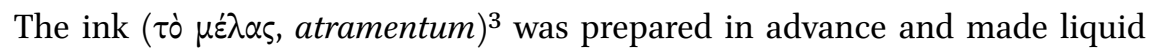
when needed. ${ }^{4}$ It was usually kept in two containers (one for black, one for red ink) that together formed the inkpot ( $\mu \varepsilon \lambda \alpha v 0 \delta \circ \chi \varepsilon \hat{o} 0 v$, atramentarium). ${ }^{5}$ When the writing instrument ( $\alpha \dot{\alpha} \lambda \alpha \mu \circ \varsigma$, calamus) was dipped into the ink, the liquid accumulated in the fissure at one end of it.

Carbon-based ink is particularly resistant — as it is chemically inert ${ }^{6}$ — but can easily be erased by scraping. ${ }^{7}$ There seems to be documentary evidence that already in antiquity metallic ink was used in some cases: it was produced from

Altertumswissenschaft, 1940, Suppl. 7: 1574-1579, p. 1576; Viktor Gardthausen, Das Buchwesen im Altertum und im byzantinischen Mittelalter (Leipzig: Veit \& Comp., 1911), p. 193 and 203; the source is Diocletian's edict De pretiis rerum venalium, 19,11; see Siegfried Lauffer, Diokletians Preisedikt (Berlin: De Gruyter, 1971, p. 151).

3 Both terms can refer to different types of dark pigment, i.e. not only to black ink, cf. Herzog Hauser, Tinte (cit. note 2), pp. 1574-1575.

4 Cf. Demosthenes, De corona, 258: $\tau \dot{\partial} \mu \varepsilon^{\prime} \lambda \alpha \nu \tau \rho \dot{i} \beta \omega \nu$, with reference to the action of grinding coal; Galenus, De simplicium medicamentorum temperamentis ac facultatibus, vol. 12 p. 226

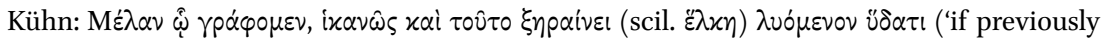
solved in water, black ink can be used to dry up ulcers'); cf. also Gardthausen, Buchwesen, p. 203; Javier Alonso, Rafael Sabio González, José Manuel Jerez Linde, "Tinteros de bronce romanos de Augusta Emerita," Archivo Español de Arqueología, 2019, 92:251-269, p. 253.

5 Mario Capasso, Introduzione alla papirologia (Bologna: Il Mulino, 2005), p. 109.

6 Fredrik C. Störmer, I. Lorentzen, Brynjulf Fosse, Mario Capasso, Knut Kleve, "Ink in Herculaneum," Cronache Ercolanesi, 1990, 20:183-184, p. 183; Mario Capasso, Manuale di papirologia ercolanese (Galatina: Congedo Editore, 1991), p. 222.

7 See Monique Zerdoun Bat-Yehouda, Les encres noires au Moyen Âge (Paris: Éditions du CNRs, 1983), p. 15 . 
a mixture of metallic salts (iron or copper sulphate) with tannin extracted from oak galls. The oldest evidence dates back to the 3 rd century. ${ }^{8}$ Notwithstanding, it took until parchment was established as the main writing support in the $5^{\text {th }}$ century for its use to spread widely. ${ }^{9}$ Mixed carbon-based inks with the addition of metallic components such as iron, copper or lead have also been documented. ${ }^{10}$ The use of metallic components in the manufacture of ink entails this becoming much more aggressive when used on papyrus than ink based on carbon black. ${ }^{11}$ Moreover, when used on parchment, such type of ink adheres better to the writing surface. ${ }^{12}$

The treatment of papyrus fibers with binding substances containing milk, casein, egg white, gum arabic and starch prevented dispersal of the ink on the

8 See Zerdoun, Encres (cit. note 7), pp. 16-17 and 91-92. See also Dioscorides, De materia

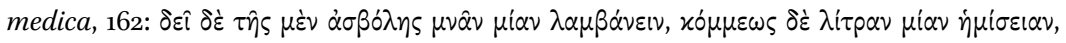

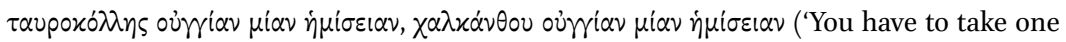
mna of soot, one and a half litre of gum, one and a half uncia of glue made from bulls' hides, and one and a half uncia of copper sulphate'). On ancient accounts concerning the composition of vitriol, see Vladimir Karpenko, "Vitriol in the History of Chemistry," Chemicke Listy, 2002, 96(12):998-1005, p. 998. An updated overview of the different types of ink in Antiquity based on physico-chemical analysis is offered in Ira Rabin, Myriam Krutzsch, "The Writing Surface Papyrus and its Materials. 1. Can the writing material papyrus tell us where it was produced? 2. Material study of the inks," in Proceedings of the 28th International Congress of Papyrology, Barcelona 2016, edited by Alberto Nodar and Sofía Torallas Tovar (Barcelona: Publicaciones de l'Abadia de Montserrat, 2019), pp. 773781, pp. $77^{6-779}$.

9 Adam Bülow-Jakobsen, "Writing Materials in the Ancient World," in The Oxford Handbook of Papyrology, edited by Roger Bagnall (Oxford: Oxford University Press, 20o9), pp. 3-29 (p. 18); Thomas Christiansen, "Manufacture of Black Ink in the Ancient Mediterranean," Bulletin of the American Society of Papyrologists, 2017, 54:167-195, p. 188.

10 Christiansen, Manufacture (cit. note 9), p. 169. P.Leid. v (= P.Leid I 384 verso= PGM/PDM $\mathrm{XII}=\mathrm{TM} 55954)$ preserved in the Leiden National Museum of Antiquities (Rijksmuseum van Oudheden), and dated to the 3 rd century AD, contains the complete recipe of a metallogallic ink (made of metallic salt, oak gall, and gum) with the addition of two additives (myrrh and truffle) [Greek text in: Karl Preisendanz, Papyri Graecae Magicae. Die griechis-

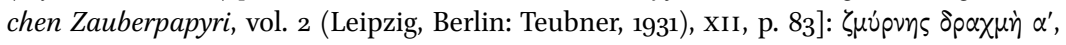

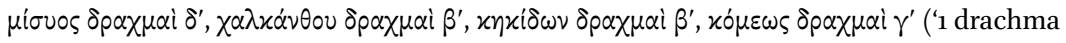
of myrrh, 4 darachmae of truffle, 2 drachmae of copper sulphate, 2 drachmae of oak gall, 3 drachmae of gum'). There are testimonies on a pigment made from cuttlefish ink (Herzog Hauser, Tinte (cit. note 2), p. 1577; Zerdoun, Encres (cit. note 7), pp. 90-91). The coloured inks were obtained from mineral pigments, such as hematite (iron oxide) in the case of red ink: see Capasso, Introduzione (cit. note 5), p. 110; Richard Parkinson, Stephen Quirke, Papyrus (London: British Museum Press, 1995), p. 44. Ovidius, Ars amatoria, 3, 627-63o, informs us about the production of 'invisible' inks.

11 Bülow-Jakobsen, Writing Materials (cit. note 9), p. 18.

12 See Zerdoun, Encres (cit. note 7), pp. 19-20. 
surface during the writing process. ${ }^{13}$ Ink absorption could be minimized by polishing the papyrus to smoothen the writing surface; excessively porous fibers, on the other hand, could lead to the absorption of too much ink and, consequently, to the formation of stains, sometimes even forcing the scribe to cut off the affected part of the roll and re-glue the remaining sections. ${ }^{14}$ In the case of palimpsest papyri, the ink was washed away by treating the papyrus with a wet sponge and, probably, by rubbing it - in order to reuse the roll without writing on the verso. ${ }^{15}$

\section{The Herculaneum Collection}

The Herculaneum scrolls were found between $175^{2}$ and 1754 during an excavation campaign commissioned by King Charles VII of Bourbon. The excavations began in 1750 and led to the development of a system of underground passages where the diggers also came across a building later hypothetically identified as a suburban residence (known as Villa dei Papiri) once owned by L. Calpurnius Piso Caesoninus, father-in-law of Julius Caesar. ${ }^{16}$ At first glance,

13 Capasso, Introduzione (cit. note 5), p. 76. On the contrary, no treatment with other substances seems to have been necessary to ensure that the papyrus fibers adhere to each other: see Bridget Leach, John Tait, "Papyrus," in Ancient Egyptian Materials and Technology, edited by Paul T. Nicholson and Ian Shaw (Cambridge: CUP, 2000), pp. 227253 (pp. 233-234); Tiziano Dorandi, "praeparatur ex eo charta. Per una rilettura del capitolo di Plinio (Nat. Hist. XIII 71-83) sulla fabbricazione della carta di papiro," Zeitschrift für Papyrologie und Epigraphik, 2017, 202:84. I would like to thank Miriam Blanco and Matteo Martelli for bringing these references to my attention.

14 Capasso, Introduzione (cit. note 5), p. 77. Cf. Zerdoun, Encres (cit. note 7), p. 14.

15 Parkinson, Quirke, Papyrus (cit. note 10), p. 47; Zerdoun, Encres (cit. note 7), pp. 85-88. Cf. Martialis, Epigrammata, 4, 10, 5-8: comitetur Punica librum / spongia: muneribus convenit illa meis. / Non possunt nostros multae, Faustine, liturae / emendare iocos: una litura potest ('The book must be accompanied by a Punic sponge: it is suitable for my gifts. Not even many erasures, Faustinus, can emend my jokes: but one single can'); Suetonius, Augustus, 85: tragoediam magno impetu exorsus, non succedenti stilo, abolevit quaerentibusque amicis, quidnam Aiax ageret, respondit Aiacem suum in spongiam incubuisse ('Because his style did not satisfy him, he destroyed the tragedy to which he had dedicated himself with great enthusiasm. To the friends who asked him, how was his Ajax, he answered that "his Ajax had thrown himself on the sponge"'). There is evidence of the existence of a solution based on saffron, water, earth, milk and lentisk juice that ensured a perfect erasure of the previous text: see Capasso, Introduzione (cit. note 5), p. 92. On the solution to whiten pearls used to prepare a palimpsest (P.Holm. No. 12), cf. Robert Halleux, Les alchimistes Grecs (Paris: Belles Lettres, 2010), p. 114.

16 For an overview of the question, see Mario Capasso, "Who Lived in the Villa of the Papyri at Herculaneum - A Settled Question?," in The Villa of the Papyri at Herculaneum, edited by Mantha Zarmakoupi (Berlin/New York: De Gruyter, 2010), pp. 89-113; Kenneth 
the papyri preserved in the house were mistaken for carbonised wooden pieces or fishing (or hunting) nets, ${ }^{17}$ hence a number of them was discarded as material of little significance. Once recognised for what they actually were, the scrolls, still closed and heavily warped by pyroclastic material (ca. 300$35{ }^{\circ} \mathrm{C}$ ) that had fallen upon the area during the eruption of Mount Vesuvius in $79 \mathrm{AD},{ }^{18}$ were kept in the Museo Ercolanese in Portici (1758) and later moved to the Museo Archeologico Nazionale in Naples (1806). A first, highly invasive method of unrolling them, known as scorzatura, ${ }^{19}$ involved vertically cutting the closed roll into two hemi-cylinders and progressively scraping off the layers of each of them, starting from the innermost layer and cutting one's way to the external layer, in order to reach each written surface. The text was copied by professional draftsmen, then the upper layer was scraped again in order to expose the underlying layer and so on. This technique, the consequence of which was the destruction of the main part of the papyrus roll (except for the outer layers, which are still preserved today and named scorze, 'peels'), was progressively replaced from 1754 onwards by a machine invented by the Genoese priest Antonio Piaggio. The new mechanism allowed for the unrolling of the scrolls while preserving most of the original layers. The outer layer was slowly detached from the underlying one, reinforced with goldbeater's skin, then cut and fixed on a paper sheet. ${ }^{20}$ In 1800 the Prince of Wales (the future king George IV) obtained from Ferdinand IV of Bourbon the authorization to send to Naples John Hayter, his personal chaplain who had studied Classics in Eton and Cambridge, in order to speed up the unrolling, transcription and publication of the papyri. From 1802, Hayter was in charge of coordinating the work on the papyri. ${ }^{21}$ The series of pencil facsimiles now stored in the Bodleian Library (Oxford) was mainly issued in this period. A first comprehensive edition of Herculaneum texts was published with the title Herculanensium voluminum quae supersunt collectio prior (1793-1855, in 11 volumes) and contained the Greek text along with a Latin translation and a commentary. The second part of the collectio (Collectio altera) followed a decade later (1862-1876, also in

Lapatin (ed.), Buried by Vesuvius. The Villa dei Papiri at Herculaneum (Los Angeles: Getty Publications, 2019); Francesca Longo Auricchio, Giovanni Indelli, Giuliana Leone, Gianluca Del Mastro, La villa dei Papiri. Una residenza antica e la sua biblioteca (Roma: Carocci, 2020).

17 Capasso, Manuale (cit. note 6), p. 68.

18 On the precise date of the eruption, see Mario Capasso, "La biblioteca di Ercolano. Cronologia, formazione, diffusione," Papyrologica Lupiensia, 2017, 26:42-68, p. 44.

19 Capasso, Manuale (cit. note 6), p. 89.

20 See now Sofia Maresca, "Early Attempts to Open and Read the Papyri: 1750s-199os," in Lapatin, Buried by Vesuvius (cit. note 16), pp. 28-36; Longo Auricchio, Indelli, Leone, Del Mastro, Villa (cit. note 16), pp. 59-64.

Capasso, Manuale (cit. note 6), p. 100 n. 53. 
11 volumes): it only displayed engravings of new texts based on pencil facsimiles (the so-called Neapolitan drawings). In 1914, after a long and difficult preparation, a third part appeared, edited by Domenico Bassi (Collectio tertia). Bassi, who in 1906 was appointed director of the Officina dei Papiri Ercolanesi, the institution that is still in charge of the preservation of the scrolls (the Officina is now hosted in the Biblioteca Nazionale di Napoli; until 1928 it was part of the Museo Archeologico Nazionale) undertook a new cataloguing of the papyri. Subsequently, many of them were placed in special boxes (cornici, 'frames') for the first time. Meanwhile, the scholarly work on the texts continued. Between the end of the 19th and the first half of the 2oth century, important critical editions were published in Germany and in Italy. A systematic publication of the papyri based on modern ecdotic criteria has been undertaken at the beginning of the 1970s, when Prof. Marcello Gigante established a chair of Herculaneum papyrology at the University of Naples and founded the Centro Internazionale per lo Studio dei Papiri Ercolanesi (CISPE).

The Herculaneum scrolls have an inestimable value not only with regard to the history of books and writing in antiquity, but also as witnesses to a period in the history of ancient thought that often lacks direct sources, i.e. that between the 3 rd and the ist century Bс. In particular, we would know little

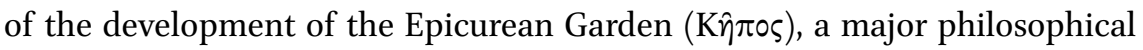
school of the Hellenistic era, without the essential contribution of the texts found in Herculaneum. It is still a matter of discussion how the library of the Villa had come to contain the selection of books it held at the moment of the eruption. ${ }^{22}$ We know that a number of the books were brought to Italy by Philodemus of Gadara. ${ }^{23}$ Philodemus was a pupil of Zeno of Sidon, who led the Epicurean school in Athens from circa 100 until 75 BC. Following Zeno's death, Philodemus went to Italy and probably took up residence in the Villa. The findings of the last forty years confirm that the library contained volumes belong-

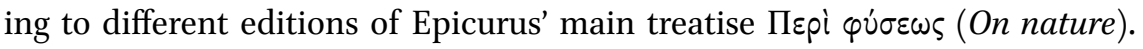
This bulky work in 37 books, probably written between the end of the 4th and the beginning of the 3rd century $\mathrm{BC}$, is a complex and challenging testimony of Epicurus' teaching and research, which survived almost exclusively in the Herculaneum papyri. Modern scholarship has been able to retrieve about a

22 On this issue, see Tiziano Dorandi, "La nuova cronologia della 'Villa dei Papiri' a Ercolano e le sorti della biblioteca di Filodemo," Würzburger Jahrbücher für die Altertumswissenschaft, 2017, 41:181-203; Capasso, Biblioteca (cit. note 18); Longo Auricchio, Indelli, Leone, Del Mastro, Villa (cit. note 16), pp. 137-191.

23 See Francesca Longo Auricchio, Giovanni Indelli, Gianluca Del Mastro, "Philodème de Gadara," in Dictionnaire des philosophes antiques, edited by Richard Goulet (Paris: Éditions du CNRS, 2011), vol. 5, pp. 334-359. 
third of the treatise, albeit in an often-fragmentary state. ${ }^{24}$ But the core of the library, as it could be hitherto reconstructed, consists of Philodemus' own works. As far as we can surmise, based on the extant material, Philodemus' interests focused on the history of philosophy and biography, ethics, theology, music, rhetoric, poetics and epistemology. The Epicurean Demetrius Laco - a contemporary of Zeno of Sidon - is also well represented in the Herculaneum collection: his extant output concerns both philological and philosophical issues. Among the other Epicureans whose writings have been fragmentarily preserved in Herculaneum, Metrodorus, Hermarchus, Polyaenus, Carneiscus, Colotes, Idomeneus and Polystratus should be mentioned as well. ${ }^{25} \mathrm{~A}$ smaller group of texts represents Stoic writers, such as Chrysippus, and Latin authors. ${ }^{26}$

Ink in Herculaneum

The visibility of the ink on the carbonised papyri must have been much better immediately after their discovery than it is now. In his Sendschreiben von den Herculanischen Entdeckungen (Dresden, 1762), Winckelmann writes: (p. 83): "The ink of the ancients was not as fluid as ours, and it was not made with vitriol. This can be seen from the colour of the letters, which is even darker than the carbonised papyrus: this makes reading much easier."27 Despite the particular resistance of carbon-based ink, however, in some cases the carbonisation process that took place during the eruption, together with chemical reactions over the centuries until their discovery, has resulted in the total or partial disappearance of the ink from the writing support. ${ }^{28}$

24 See Giuliana Leone, "Osservazioni sui papiri ercolanesi di Epicuro," Studi di Egittologia e Papirologia, 2014, 11:83-109; Tiziano Dorandi, "Modi e modelli di trasmissione dell'opera Sulla Natura di Epicuro," in Questioni Epicuree, edited by Dino De Sanctis, Emidio Spinelli, Mauro Tulli, and Francesco Verde (Sankt Augustin: Academia Verlag, 2015), pp. 15-52.

25 See Michael Erler, "Die Schule Epikurs," in Grundriss der Geschichte der Philosophie. Die Philosophie der Antike, IV.1, edited by Hellmut Flashar (Basel: Schwabe, 1994), pp. 203-362.

26 On the Latin papyri from Herculaneum, see Mario Capasso, Les papyrus latins d'Herculanum: Découverte, consistance, contenu (Liège: CEDOPAL, 2011); further Capasso, Biblioteca (cit. note 18), pp. 64-68.

27 "Die Tinte der Alten war nicht so flueßig, wie die unsrige, und war nicht mit Vitriol gemacht. Dieses kann erstlich aus der Farbe der Buchstaben geurtheilt werden, welche schwärzer noch, als die gleichsam in Kohlen verwandelten Schriften sind, wodurch das Lesen derselben sehr erleichtert wird."

28 See Capasso, Biblioteca (cit. note 18), p. 45. Cf. Francesco Sbordone, "Recenti tentativi di svolgimento dei papiri ercolanesi," Cronache Ercolanesi, 1971, 1:23-39, p. 25, reporting the opinion of the Austrian restorer Anton Fackelmann: "Although the rolls have a length of $150-180 \mathrm{~cm}$, only scanty remains of letters appear in a few places. Unfortunately, the 


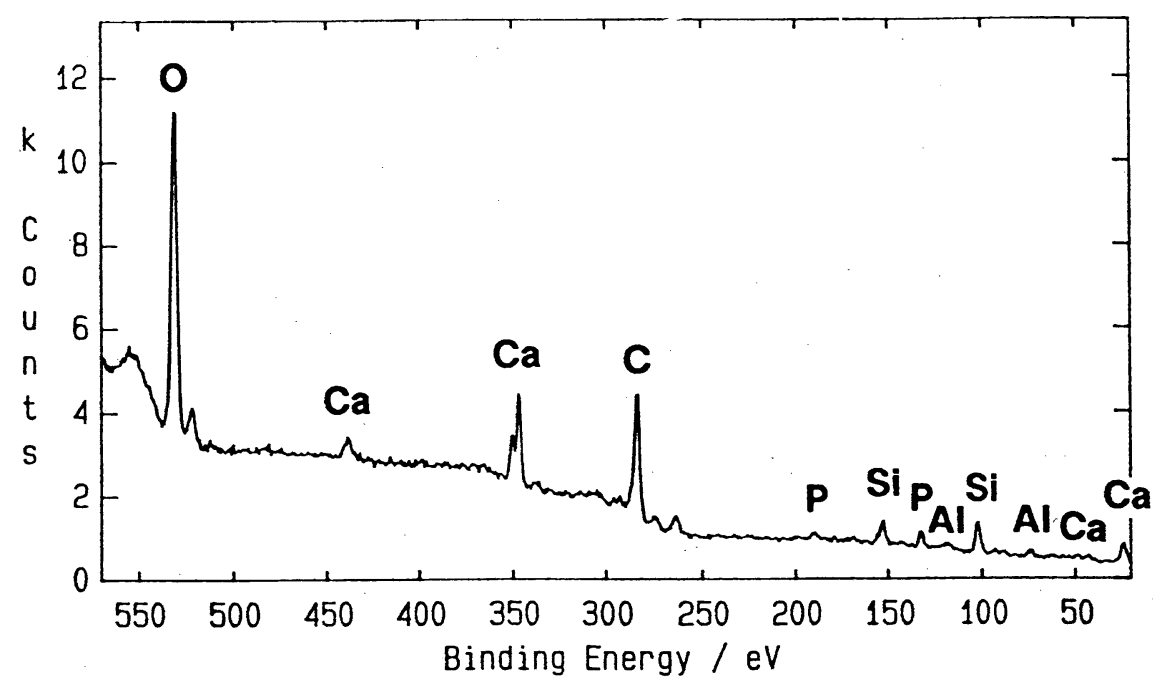

FIGURE 3.1 Energy spectrum of the surface of a papyrus of Herculaneum, obtained through the use of an electron microscope and an energy-dispersive X-ray analyzer

Experiments conducted between the end of the 1980s and the beginning of the 199os concerning the ink composition of some fragments of the Herculaneum collection confirm that the scrolls essentially correspond with the Greek papyri found in the sands of Egypt, since their ink is primarily carbon-based (Fig. 3.1). ${ }^{29}$

About a decade ago, an article by Brent Seales ${ }^{30}$ outlined the first results of analyses performed on Herculaneum papyri using different imaging methods, from X-ray techniques (EDX, PIXE) to magnetic resonance imaging (MRI) and computed tomography (CT). It established the main criteria to be considered in order to obtain a sufficient contrast between writing and support: 1) the difference in density between ink and papyrus; 2) the morphology of the writing, which in various ways interacts with the support and produces

ancient Egyptian soot ink is much more resistant than the Roman ink. The Egyptian ink is a gum-resin mixture with soot, an ink that can also be placed in boiling water if necessary (mummy cartonnage). In Italy, on the other hand, the ink (according to Pliny) was made with grated charcoal and gum, an ink that adheres more to the surface and tends to form dust."

29 Störmer, Lorentzen et al., Ink (cit. note 6), p. 183. For a review of recent applications of experimental sciences to the Herculaneum Papyri see Gianluca Del Mastro, "Papyrology and Experimental Sciences," Research Trends In Humanities Education \& Philosophy, 2019, 6:8-15.

$30 \quad$ W. Brent Seales, "Lire sans détruire les papyrus carbonisés d'Herculanum," Comptes rendus des séances de l'Académie des Inscriptions et Belles-Lettres, 2009, 153(2):907-923. 
specific structural features; and 3) the chemical-physical analysis of the elements that constitute the ink and the papyrus. The analyses carried out on some fragments resulted in the identification of calcium (Ca) as a possible distinctive element between ink and papyrus (with the concentration of calcium (Ca) being correlated to the areas where the ink is present $)^{31}$ and the detection of lead $(\mathrm{Pb})$ and strontium $(\mathrm{Sr})$ (which was not found during the experiments by Störmer, Lorentzen et al.) in the ink's composition. ${ }^{32}$

In any case, it has still proven impossible to distinguish the writing of unwound papyrus rolls from carbonised fibres using conventional X-ray techniques based on the different level of absorption of the rays to which the object is exposed. ${ }^{33}$ The study of the ink composition in Herculaneum has therefore been the subject of new research in recent years. Interesting results have been achieved through the introduction of innovative screening methods, such as X-Ray Phase Contrast Tomography (ХРCT), a technology sensitive to materials with similar characteristics, as in the case of the carbon-based ink used for writing and the carbonised surface of the papyri (both of which exhibit weak levels of absorption). ${ }^{34}$ The possibility of distinguishing the writing from the surface presupposes the identification of the precise chemical composition of the ink, which determines the choice of the optimal X-ray wavelength, in order to achieve sufficient contrast to make the writing legible. ${ }^{35}$ Another physical feature that helps to isolate the ink is the fact that it usually shows a slight relief from the surface of the papyrus (the carbon black ink does not completely penetrate the fibres), causing the X-rays to undergo a minimum deviation at that point. ${ }^{36}$

31 Seales, Papyrus carbonisés (cit. note 30), p. 914; cf. W. Brent Seales, Daniel Delattre, "Virtual Unrolling of Carbonized Herculaneum Scrolls: Research Status (2007-2012)," Cronache Ercolanesi, 2013, 43:191-208, p. 196.

Seales, Papyrus carbonisés (cit. note 30), p. 917; cf. Seales, Delattre, Virtual Unrolling (cit. note 31), pp. 197-198.

33 Ana S. Leal, Silvia Romano, Vito Mocella, "Ink Study of Herculaneum Papyri," Manuscript Cultures, 2018, 11:17-20, p. 17; but see also Clifford Seth Parker, Stephen Parsons, Jack Bandy et al., "From invisibility to readability: Recovering the ink of Herculaneum," PLoS ONE 14(5): eo215775 [DOI: 10.1371/journal.pone.0215775].

34 Gianluca Del Mastro, Daniel Delattre, Vito Mocella, "Una nuova tecnologia per la lettura non invasiva dei papiri ercolanesi," Cronache ercolanesi, 2015, 45: 227-230, p. 229; Vito Mocella, Emmanuel Brun, Claudio Ferrero, Daniel Delattre, "Revealing Letters in Rolled Herculaneum Papyri by X-Ray Phase-contrast Imaging," Nature Communications, 2015, 6 (5895):2-6, p. 2.

35 Leal, Romano, Mocella, Ink (cit. note 33), pp. 17, 18; Del Mastro, Delattre, Mocella, Tecnologia (cit. note 34), p. 228.

36 Del Mastro, Delattre, Mocella, Tecnologia (cit. note 34), pp. 228, 23o; Mocella, Brun et al., Revealing Letters (cit. note 34), p. 3. Cf. Seales, Papyrus carbonisés (cit. note 30), p. 912. 


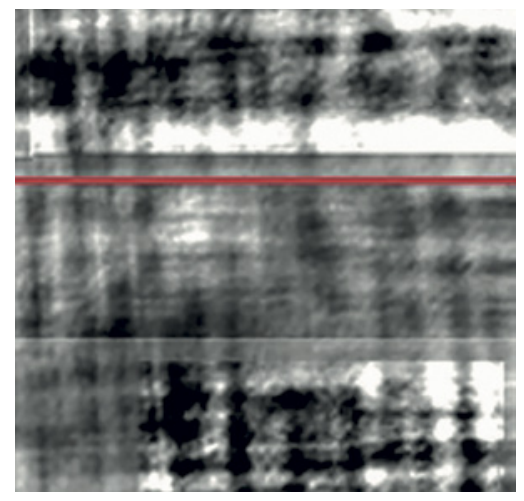

FIGURE 3.2

Results of the scan of PHerc.Paris. 1

Initial experiments with the application of XPCT on Herculaneum papyri were conducted in December 2013 by a team led by the Italian physicist Vito Mocella at the ESRF (European Synchrotron Research Facility) in Grenoble, France ${ }^{37}$ There, two rolls from the collection of the Institut de France, donated to Napoleon Bonaparte by Ferdinand IV of Bourbon in 1802, ${ }^{38}$ (PHerc.Paris. 4 , rolled; PHerc.Paris. 1, a fragment with several layers of papyrus superimposed on each other) were subjected to radiation from one of the light lines produced by the synchrotron through the magnetically induced deviation of accelerated electrons (ID 17). The diffraction of the X-ray beam, which was then processed into three-dimensional images, revealed short sequences of letters. For PHerc.Paris. 1 it was possible to identify the verbal forms піптоге (presumably from $\pi i \pi \tau \omega$, "to fall") and ЕІпо (perhaps from a verbum dicendi) (Fig. 3.2). ${ }^{39}$

The scan of PHerc.Paris. 4, which has a very complex morphology due to it being exposed, at the time of the eruption, to considerable pressure that has greatly deformed its structure, revealed some groups of letters, which can be interpreted, with due caution, as APN, HEY and KI (Fig. 3.3).

Similar results were obtained in a series of experiments conducted simultaneously and independently by another team of scientists, who combined XPCT with three-dimensional computation algorithms - known as "virtual unrolling" - adapted to the particular structural deformations of the

37 A previous synchrotron light experiment was conducted at the Stanford Linear Accelerator without any decisive results in ink detection: see Seales, Delattre, Virtual Unrolling (cit. note 31), p. 206.

38 Cf. Marcello Gigante, "I papiri ercolanesi e la Francia," in Contributi alla storia della Officina dei Papiri Ercolanesi 2, a cura di Marcello Gigante (Roma: Istituto Poligrafico e Zecca dello Stato, 1986), pp. 27-35.

39 Mocella, Brun et al., Revealing Letters (cit. note 34), p. 3. 

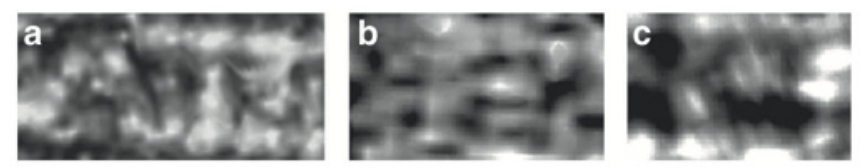

FIGURE 3.3 Results of the scan of PHerc.Paris. 4

Herculaneum papyri. They also managed to make some portions of text from still rolled scrolls visible (PHerc. 375 and PHerc. 495) ${ }^{40}$

Recent analyses carried out on some fragments of Herculaneum papyri by synchrotron X-ray-based techniques have shown the presence of lead (in a state similar to lead (II) acetate) within the ink - a surprising result that challenges the communis opinio on the exclusively carbon-based composition of Herculaneum ink. Hypotheses have been made regarding the causes of this phenomenon, which may be due to:41

a) Contamination of the water used to fabricate the inks.

b) The presence of lead in the bronze containers in which the ink was stored.

c) An intentional use, either as an additional pigment or as a binding medium to accelerate the drying process. ${ }^{42}$

According to Tack, Cotte et al. (cit. note 41), the concentration of lead detected in the ink of the fragments used as test samples is too high $(11-21 \mu \mathrm{g} / \mathrm{cm} 2$ in

40 Inna Bukreeva, Alberto Mittone, Alberto Bravin, Giulia Festa, Michele Alessandrelli, Paola Coan, Vincenzo Formoso et al., "Virtual Unrolling and Deciphering of Herculaneum Papyri by X-Ray Phase-Contrast Tomography," Scientific Reports, 2016, 6 (27227):2-6. See also, more recently, Inna Bukreeva, Graziano Ranocchia, Vincenzo Formoso, Michele Alessandrelli, Michela Fratini, Lorenzo Massimi, Alessia Cedola, "Investigation of Herculaneum Papyri by X-Ray Phase-Contrast Tomography," in Nanotechnologies and Nanomaterials for Diagnostic, Conservation and Restoration of Cultural Heritage. A Volume in Advanced Nanomaterials, edited by Giuseppe Lazzara and Rawil Fakhrullin (Amsterdam [etc.]: Elsevier, 2019), pp. 299-324, which integrates the results of the previous study with an extensive report on the material characteristics (such as the arrangement of whorls after the mechanical action of the pyroclastic material, the damage occurred at the time of the eruption and during cataloguing and storage, the presence of foreign bodies such as sand and pebbles) of the rolled volumes subjected to XPCT. On the first virtual unrolling experiments conducted on the papyri of Herculaneum see Seales, Delattre, Virtual Unrolling (cit. note 31).

41 See Pieter Tack, Marine Cotte, Stephen Bauters, Emmanuel Brun, Dipanjan Banerjee, Wim Bras, Claudio Ferrero et al., "Tracking Ink Composition on Herculaneum Papyrus Scrolls: Quantification and Speciation of Lead by X-Ray Based Techniques and Monte Carlo Simulations," Scientific Reports, 2016, 6 (20763):1-7, p. 2; Lars Krutak, "Ink," in The Encyclopedia of Archaeological Sciences, edited by Sandra L. López Varela (Malden, MA: Wiley-Blackwell, 2019), pp. 942-945, p. 943.

Cf. Zerdoun, Encres (cit. note 7), p. 16 on the influence of additives on ink properties. 

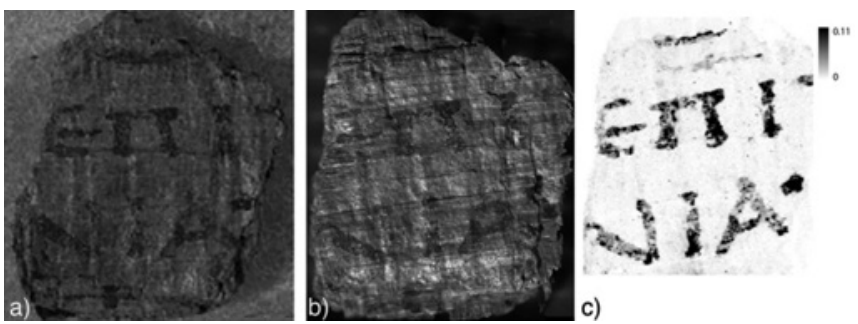

FIGURE 3.4 Comparison of natural light images (a), infrared images

(b) and the lead distribution map obtained by using $\mathrm{X}$-rays

one case, $79-89 \mu \mathrm{g} / \mathrm{cm} 2$ in the other) to be traced back to contamination of the water used as a solvent (the average value in the latter case being less than $1.5 \mathrm{mg} / \mathrm{L}$ ) or to the storage of the pigments in bronze containers (unlike lead, no co-distribution of copper $(\mathrm{Cu})$ with the writing was detected). ${ }^{43}$ The authors of the study consider it more likely that the presence of lead is due to an intentional addition as a pigment or as a drying agent: ${ }^{44}$ this would lead to classifying the ink used in some of the papyri as a "mixed type" ink. ${ }^{45}$ The importance of this discovery is the possibility of using lead as a contrast agent to bring out the writing on the support. In the study by Brun, Cotte et al., the mapping of the presence of lead in two fragments by synchrotron rays allows for the visualization of groups of letters even more clearly than in natural light or infrared photographs (the latter obtained at a wavelength of $940 \mathrm{~nm})^{46}$ (Fig. 3.4).

In comparison with the distribution maps of other elements detected in the composition of the ink, lead seems thus to be the best element for discriminating between ink and writing support. ${ }^{47}$ Leal, Romano et al. have

43 Tack, Cotte et al., Ink Composition (cit. note 41), p. 3; cf. Emmanuel Brun, Marine Cotte, Jonathan Wright, Marie Ruat, Pieter Tack, Laszlo Vincze, Claudio Ferrero et al., "Revealing Metallic Ink in Herculaneum Papyri," Proceedings of the National Academy of Sciences of the United States of America, 2016, 113 (14):3751-3754, p. $375^{2}$.

44 Tack, Cotte et al., Ink Composition (cit. note 41), p. 5 .

45 See. n. 10; Zerdoun, Encres (cit. note 7), p. 20: "Ce sont par exemple des encres au carbone auxquelles le préparateur a ajouté des extraits aqueux de produits tannants ou des sels métalliques."

46 On infrared images of the Herculaneum papyri, see Steven W. Booras, David R. Seely, "Multispectral Imaging of the Herculaneum Papyri," Cronache Ercolanesi 1999, 29:95-100. Recent developments, such as their use in combination with RTI (Reflectance Transformation Imaging), are reported in Kathryn Piquette, "Illuminating the Herculaneum Papyri: Testing New Imaging Techniques on Unrolled Carbonised Manuscript Fragments," Digital Classics Online, 2017, 2(1):80-102.

Brun, Cotte et al., Metallic Ink (cit. note 43), p. 3752. (Leal, Romano et al., Ink, p. 19). 
recently published the results of an experiment conducted on facsimiles of Herculaneum papyri, in which a fragment of papyrus written with blue ink containing lead (II) acetate was placed inside a roll of papyrus written using commercial Chinese black ink and subsequently scanned by ХРСТ: the experiment reveals that it is possible to decipher, in the three-dimensional reconstruction of the roll, some letters written on the fragment with ink containing lead.

Nevertheless, claiming that the inks of the Herculaneum papyri all contained lead would be incorrect. The absence of this element in the results of the study published in 2015 by Mocella, Brun et al. (cit. note 34) rather suggests that the composition of the inks may have varied according to the chronology of the papyri (which, in the case of the library of Herculaneum, covers a spectrum of at least three centuries, from the 3 rd cent. $\mathrm{BC}$ to the end of the 1 st cent. $\mathrm{AD})$ and the scribes who copied the texts. ${ }^{48}$ Still, the results of the aforementioned studies represent an important starting point for the development of more refined techniques capable of better distinguishing the writing without the need to handle extremely fragile artefacts, thus ensuring their preservation.

48 Ibid., pp. 3752-3753. See Zerdoun, Encres (cit. note 7), p. 13: "En effet, pour une recette d'encre possédant les mêmes composants de base, mélanger ceux-ci en proportions différentes peut donner une encre de réactivité chimique variable avec, pour conséquence, des effets divers sur le support. Ne serait-ce pas ce qui s'est souvent produit lorsque les scribes, à partir d'une recette donnée, auraient, pour une raison quelconque, changé les proportions, créant ainsi une encre de même nature, mais de réactivité différente ?" On the dating of the Herculaneum papyri see Capasso, Manuale (cit. note 6), pp. 151-198 and Capasso, Biblioteca (cit. note 18 ), pp. 47-50. 